\title{
China as an Emerging Actor in Conflict Management: from Non-Interference in Internal Affairs to “Constructive” Engagement
}

\author{
A.V. Khudaykulova \\ Moscow State Institute of International Relations (MGIMO-University), MFA of Russia, \\ Moscow, Russian Federation \\ RUDN University, Moscow, Russian Federation
}

\section{Китай в урегулировании конфликтов: от невмешательства во внутренние дела к «конструктивному» вовлечению}

\section{А.В. Худайкулова}

Московский государственный институт международных отношений (МГИМО-Университет), МИД России, Москва, Российская Федерация Российский университет дружбы народов, Москва, Российская Федерация

\begin{abstract}
The need to protect citizens and investments abroad is placing tremendous pressure on China's traditional foreign policy strategy and noninterference principle. Instability in most of BRI countries form new security conditions, pushing China to be more flexible in engaging in missions it had previously opposed, including political engagement in intrastate conflicts in the developing world. Following the formula "politics is a big economy", China starts rethinking its security interests. As a result, China has smoothly adopted the transition strategy from non-intervention into internal affairs to a more proactive non-indifference approach, that Chinese academics are describing as "creative" or "constructive" engagement. Many new elements contribute to this new constructive engagement - conceptual narrative, political support, geopolitical competition, growing capacities and new security conditions.

The key point of the article is to analyze China's strategy in defending national interests overseas, including the rescue and peacekeeping operations, mediation, political envoys, etc. The special focus is done on proactive peacekeeping policy of China and its new role in the security environment. Obviously, in future China will follow implementing the overseas missions, including humanitarian assistance and disaster relief, evacuation operations, defense of sea lanes, stabilization operations, peacekeeping and counterterrorism missions. After launching in 2017 its first overseas military base in Djibouti, there is little evidence to predict that in the near future China intends to construct more bases. But nevertheless the geopolitical rivalry with the United States might push China to convert three deep-water ports — Gwadar (Pakistan), Salalah (Oman), and Seychelles ports into naval bases. The degree of the China's involvement in global security landscape will depend on the level of its responsibility, since Beijing is undergoing through a higher degree of international pressure in order to take more obligations. Responding to overseas security crises through military actions would be mostly shaped by events (case-by-case approach), inspired by political motivations and organized as small-scale and low-intensity missions.
\end{abstract}

Key words: China, security, conflict resolution, intrastate conflicts, peacekeeping, non-interference, constructive engagement, mediation

Acknowledgments: The research was funded by RFBR and EISR according to the scientific project № 19-011-31389 "Traditional and emerging powers: discussions on sovereignty and conflict management".

For citations: Khudaykulova, A.V. (2019). China as an Emerging Actor in Conflict Management: from Non-Interference in Internal Affairs to "Constructive" Engagement. Vestnik RUDN. International Relations, 19 (3), 420-431. DOI: 10.22363/2313-0660-2019-19-3-420-431

(C) Khudaykulova A.V., 2019

(i) This work is licensed under a Creative Commons Attribution 4.0 International License

https://creativecommons.org/licenses/by/4.0/ 
Необходимость защиты граждан и инвестиций за рубежом оказывает значимое воздействие на традиционную внешнеполитическую стратегию Китая, включая следование в русле политики невмешательства. Внутренняя нестабильность в большинстве стран, участвующих в проекте «Один пояс, Один путь», влияет на формирование новых условий в сфере безопасности, ориентируя Китай на проявление большей гибкости в миссиях по политическому урегулированию внутригосударственных конфликтов, от участия в которых Китай воздерживался еще в недавнем прошлом. Исходя из формулы «политика - это большая экономика», Китай переосмысливает свои интересы в области безопасности, в том числе на концептуальном уровне с точки зрения осторожного перехода от невмешательства к более активному «конструктивному» взаимодействию. Становлению данного концепта способствует множество факторов - академический интерес, политическая поддержка, геополитическая конкуренция, растущий потенциал и новые угрозы безопасности.

В статье изучается стратегия Китая по защите национальных интересов за рубежом, включая операции по спасению граждан и поддержанию мира, посредничество, использование специальных посланников и т.д. Особое внимание уделяется анализу проактивной миротворческой политики Китая и его новой роли в сфере обеспечения безопасности. Очевидно, что Китай будет продолжать наращивать свои зарубежные миссии, включая оказание гуманитарной помощи, содействие в случае стихийных бедствий, проведение операций по эвакуации, защите морских путей, стабилизации внутренней обстановки, а также миротворческие и контртеррористические миссии. Однако вряд ли можно ожидать, что Китай откроет новые военные базы (единственная база сегодня располагается в Джибути). Вместе с тем нарастающее геополитическое соперничество с США может подтолкнуть Китай к превращению нескольких глубоководных портов в военноморские базы. Степень вовлеченности Китая в обеспечение безопасности на глобальном уровне будет зависеть от уровня ответственности Пекина, на фоне более настойчивого давления международного сообщества по принятию больших обязательств в этой области. По всей видимости, реагирование на зарубежные кризисы безопасности, в том числе с помощью военного компонента, будет зависеть от конкретного случая, определяться политическими мотивами и проводиться в виде небольших и малоинтенсивных операций.

Ключевые слова: Китай, безопасность, урегулирование конфликтов, внутригосударственные конфликты, поддержание мира, невмешательство, конструктивное взаимодействие, посредничество

Благодарности: Исследование выполнено при финансовой поддержке РФФИ и АНО ЭИСИ в рамках научного проекта № 19-011-31389 «Традиционные и восходящие центры силы: дискуссии относительно суверенитета и управления конфликтами».

Для цитирования: Khudaykulova A.V. China as an Emerging Actor in Conflict Management: from Non-Interference in Internal Affairs to "Constructive" Engagement // Вестник Российского университета дружбы народов. Серия: Международные отношения. 2019. Т. 19. № 3. С. 420-431. DOI: 10.22363/2313-0660-2019-19-3-420-431

Although the People's Republic of China is now almost universally acknowledged as a great power, China prefers to position itself as an emerging power [Yaqing 2019; Ikenberry 2008]. But even taking this approach, it is undoubtedly the biggest non-Western emerging power of the XXI century. Advancing the official foreign policy rhetoric and commitment to the mutually beneficial peaceful development, at the 19th Congress of the Chinese Communist Party (2017), Xi Jinping announced that the time had come for the Chinese nation to become a powerful force that would have great authority on the world stage in the political, economic and military spheres ${ }^{1}$.

With this strategy in mind China in undertaking considerable efforts to become a leading power in all respects and spheres, including international security. The country's growing economic, political and cul-

1 Full text of Xi Jinping's report at 19th CPC National Congress. October 18, 2017. URL: https://www.chinadaily.com.cn/china/19thcpcnational congress/2017-11/04/content_34115212.htm (accessed: 28.10.2019). tural significance, the ability to influence the global decision-making process, the responsibility rise regarding international peace and security, the emerging image of defender of less developed unstable countries, the increasing scope of military presence and humanitarian assistance, the ongoing evolution of its Belt and Road initiatives (BRI), etc. demonstrate the China's far going foreign policy global ambitious [Cheng et al. 2019].

For the last two decades, security risks to China's overseas interests are on the increase, as the geographic scope of BRI extends over unstable regions where the security situation is dangerously explosive [Campbell et al. 2012]. So, it creates potentially risky conditions for the safety of a growing number of Chinese assets and nationals. By the end of 2016, over two million Chinese nationals were working overseas, with $90 \%$ being employed in BRI countries in Asia and Africa. The dynamics in the number of employees abroad is quite impressive, as the number of workers doubled in comparison with 2014 [Wuthnow 2017]. 
Following the formula "politics is a big economy", China starts rethinking its security interests. In this regard China's People's Liberation Army (PLA) has taken on the new challenges created by globally expanding national interests and security threats posed by political instability, social unrest, radical extremism and terrorism in most of BRI countries.

Currently China represents a very important partner for the UN peacekeeping, as the participation of the Chinese peacekeepers increases the effectiveness of peacekeeping operations under the auspices of the UN. China is one of the main suppliers of peacekeeping budget and forces. It has deployed its peacekeeping troops in Sudan, South Sudan, Lebanon, the Democratic Republic of Congo and Mali. China is increasingly active in Afghanistan, proposing options for peaceful solution to the long-standing crisis and launching at the same time promising economic projects. Proactive security strategy includes not only the greater involvement in the UN peace activities, but a new approach to peace enforcement. After the number of crises incidents (suicide bomber attack of the Chinese Embassy in Bishkek in 2016, attack of the Chinese consulate in Karachi in 2018, robbing and killing of a Chinese citizen in the Dalbeda area in 2018, beheading of two teachers in Quetta by ISIS, killing of three officers from the China Railway Construction Corporation in Bamako, etc.), China finally acknowledged the shortcomings of a tough stance regarding non-intervention and has been demonstrating more flexible policy since then.

The article addresses the issue of China's strategy in defending national interests overseas, which is relatively new as problématique. Some years earlier, analysts dismissed the very possibility of an overseas military deployment unless there was a mandate from the UNSC and a formal invitation from the host country [Duchâtel, Bräuner, Hang 2014]. But due to the current geopolitical and economic conditions China is caught between the need to maintain access to strategic resources and protecting its overseas economic interests, both of which require some degree and scope of intervention. What is the perception of the security threats for modern China? What are the Chinese strategy and methods in responding to foreign security threats, including the intrastate armed conflicts, threatening basic economic interests? How could China reconcile its commitment to nonmilitary means with the need to secure and protect its interests and citizens? Will China follow the intervention strategy as its interests are expanded and might be threatened abroad? What might be the "constructive engagement" of China in BRI involved countries?

The author's analyses include not only the conceptual framework of the China's foreign policy strategy, but its practical implementation and concrete cases of overseas interests safeguard and proactive engagement.

\section{Overseas Interests and New Security Challenges}

In the past years, China was traditionally preoccupied by the intensity of the traditional "highpolitics" security challengers along the perimeter of its borders - rivalry with Japan and India, aggravated territorial disputes in the South China Sea, North Korean nuclear issue, Uyghur separatism, the problem of Taiwan and Tibet, security threats on the Maritime Silk Road, and many others. At the same time Beijing has been facing quite new security agenda, consisting of new nontraditional security threats such as terrorist attacks, transnational organized crime, killing and kidnapping of its citizens abroad.

The issue of the safeguard of its economic interests and personal safety in politically unstable regions, a role that China seldom experienced previously, is becoming increasingly relevant. China has significantly increased the volume of its foreign investment and assistance in Asia and Africa, mainly through the implementation of massive and far-reaching Belt and Road Initiative infrastructure program (since 2013), viewed as a mechanism of projecting Chinese power across the globe. Many Western states perceive BRI as a security threat. But China's Ministry of National Defense firmly denies that BRI has any military or geostrategic intent, advancing the idea of win-win cooperation that China touts with BRI [Rolland 2019: 2].

In 2013, the Ministry of National Defense issued a white paper called "The Diversified Employment of China's Armed Forces", which referred to the PLA's missions the following tasks: defending national sovereignty, security, and territorial integrity, supporting national economic and social development, and safeguarding world peace and regional stability ${ }^{2}$.

2 White Paper 2012. The Diversified Employment of China's Armed Forces. Information Office of the State Council. The People's Republic of China. April 2013. URL: http://eng.mod.gov.cn/publications/2016-07/13/content 4768293.htm (accessed: 28.10.2019). 
China actively supports the "security-development" nexus and believes that a long-term development is the basis for regional security, and security in its turn contributes to the development [Seesaghur, Robertson 2016; Suzuki 2011]. China's 2017 White paper on Asia-Pacific Security explains clearly states that "Security and development are closely linked and mutually complementary. Equal consideration should be given to both a security framework and an economic framework - the main components of the entire regional structure - to ensure their parallel development. On the one hand, the improvement of the security framework will help ensure a peaceful and stable environment for economic development; on the other, faster regional economic integration will provide solid economic and social support for the development of the security framework"3.

Chinese scholars refer to J. Galtung theory of structural violence [Galtung 1969] and affirm that unlike Western powers aiming just at establishing negative peace (not solving social-economic contradictions in poor countries), China is aimed at providing positive peace through inclusive growth in conflict affected areas [Zhang, Zhang 2018: 4-11].

Official BRI documents and declarations of central authority demonstrate China's willingness to more actively shape the international security environment. In 2015, Xi Jinping publicly stated that the military should play a pivotal role in "the maintenance of international security affairs" and try its best to provide more "public security products to the international community"4 . Preoccupied by providing

3 Full Text: China's Policies on Asia-Pacific Security Cooperation. Xinhua, January 11, 2017. URL: http://www.xinhuanet.com//english/china/2017-01/11/ c_135973695.htm (accessed: 28.10.2019).

4 See: "Xi Jinping jieshou Huaerjie Ribao caifang" (Xi Jinping Interview with the Wall Street Journal), Xinhua, September 22, 2015. URL: http://news.xinhuanet.com/politics/ 2015-09/22/c_1116642032.htm (accessed: 28.10.2019); President Xi condemns Mali hotel attack, vows international anti-terrorism cooperation. China Daily, November 21, 2015. URL: http:/www.chinadaily.com.cn/world/2015-11/21/content 22507026.htm (accessed: 28.10.2019); Wenting X. Chinese Security Companies in Great Demand as Overseas Investment Surges. Global Times, June 23, 2016. URL: http://www.globaltimes.cn/content/990161.shtml (accessed: 28.10.2019). emergency protection to Chinese companies operating in dangerous zones, the PRC started strengthening the naval component of its armed forces, proceeding to the concept of "pearl string" in the Indian Ocean.

Many, if not majority, BRI projects are located in quite unstable and insecure regions, but with strategic ports on their territories. As Guifang Xue stresses, "investing in ports located in strategic positions no doubt helps China diversify its supply of overseas energy and raw materials, safeguard its SLOC (sea lines of communication) access and security, and improve its overall geopolitical position" [Xue 2019]. Quite challenging security situation is taking place in Pakistan around Gwadar port projects ${ }^{5}$. Chinese interests, including the China-Pakistan Economic Corridor, are more often attacked by the Baluchi Liberation Army, which claims that it is fighting the "exploitation of Baluchistan's mineral wealth and occupation of Baluch territory" by China.

The protection of BRI infrastructure projects, transport, construction units and Chinese nationals is becoming an increasingly important factor in China's engagement. In 2018, Defense Minister Wei Fenghe declared that China was ready to "provide strong security guarantees" to support BRI projects ${ }^{6}$. Beijing's strategy for enhancing the security of its interests along the Belt and Road routes includes several options.

First, construction of military bases. In 2017 China opened its first foreign naval base in Djibouti, where the contingents of the armed forces of China,

5 Pakistani Gwadar port, one of the major components of Belt and Road Initiative, has become the scene of a regional power struggle between China and Pakistan, on the one hand, and United Arab Emirates and India, on the other. In 2015, Pakistan announced the lease of a 152-hectare site in the commercial port of Gwadar to the Chinese company China Overseas Ports Holding for a period of 43 years to facilitate direct access of Chinese goods to the Persian Gulf region and the Middle East. This directly affects the largest Middle Eastern port of Jebel Ali Jeff Ali and the port of Rashid in Dubai. After it became known that China intended to invest $\$ 60$ billion in infrastructure development of the Gwadar port, the US suggested that China would open a military base there.

6 Panyue H. Chinese Defense Minister Meets Pakistani Naval Chief of Staff. China Military Online, April 19, 2018. URL: http://eng.mod.gov.cn/news/2018-04/19/content_ 4809874.htm (accessed: 28.10.2019). 
the USA, Japan and the EU were stationed side by side ${ }^{7}$. Beijing still refers to it as a "logistics complex", that is determined to be a hub for the deployment of peacekeeping troops (not realized yet), to provide logistical support for antipiracy patrols, and to support humanitarian assistance and disaster relief operations (these two tasks have already been implemented $)^{8}$. Moreover, China declares its readiness to cooperate with other countries. In sum, Djibouti military base acts as a hub for peacekeeping and other initiatives in Africa and the Indian Ocean region, helping to control maritime supply routes.

Second, close cooperation with local authorities and strengthening local forces. Thus, in 2016 Pakistan established a special security force of around 15,000 troops to protect Chinese projects and workers in the area. This method to secure the assets and interests could be evidently applied elsewhere.

Third, naval escort missions, as in the Gulf of Aden and waters off Somali for Chinese and international ships. In 2008, China supported the UN SC Resolution 1816, calling for international efforts to fight pirate activities in the Gulf of Aden'. Since December 2008, China has been constantly sending troops of PLA naval ships to the Gulf of Aden and the territorial waters of Somalia to escort ships and protect navigation [Lin-Greenberg 2010]. On 4 January 2014, Chinese frigate Yancheng joined the international escort mission for the disposal of Syrian chemical weapons in response to appeals from the UNSC and the Organization for the Prohibition of Chemical Weapons ${ }^{10}$. At the beginning of 2019, China sent a total of about 26 squadrons of ships

7 The scale of the official Chinese military presence in Africa is less visible in comparison with the western states' engagement. For instance, the United States has military bases in 34 African countries, whereas China has just one.

8 The deployment of the Peace Ark hospital ship in August 2017 illustrates the example of an HADR mission conducted in Djibouti.

9 UN Security Council. Resolution 1816 (2008). Adopted by the Security Council at its 5902nd meeting on 2 June 2008. URL: https://www.securitycouncilreport.org/atf/cf/\%7B65 BFCF9B-6D27-4E9C-8CD3-CF6E4FF96FF9\%7D/Somalia \%20S\%20RES\%201816.pdf (accessed: 28.10.2019).

10 Chinese Frigate Starts Escort Mission for Chemical Weapons: FM. Xinhua News Agency, January 8, 2014. URL: http://en.people.cn/90883/8506315.html (accessed: 28.10.2019). to the Gulf of Aden, which escorted more than 6,400 Chinese and foreign ships, found and inspected about three thousand suspicious water vehicles. Over the past decade, the Chinese navy has dispatched 106 vessels and over 28,000 officers and soldiers to escort more than 6,700 Chinese and foreign ships ${ }^{11}$.

Fourth, active formation and expansion of private military companies, which were especially active, according to unofficial data, in Sudan and South Sudan, including participating in a Sudanese army mission to rescue 29 kidnapped Chinese nationals. The employment of small-scale private forces offers more flexible and economically preferable strategy. But not many have the capability to operate in foreign countries, and most of the time they subcontract to international or local contractors [Rolland 2019: 92-103].

Obviously, Chinese government and companies have underestimated new generation security threats. The expansion of China's overseas interests naturally creates the need for their military protection. So, today's big task is to elaborate a relevant strategy how to manage the security concerns along the Belt and Road routes. There is (little) evidence that China would engage into constructing more overseas military bases in the next decade, which would be extremely costly. But this possibility is still on the agenda due to the geopolitical rivalry with the United States. At least three deep-water ports - Gwadar (Pakistan), Salalah (Oman), and Seychelles ports could be converted into naval bases. The continuing threat of terrorist attacks and military intervention as a possible reaction would foster the decision on establishing a new base. However, there is another approach, that assumes that China will not need to establish multiple bases for missions that will essentially be small-scale and low-intensity. A permanent military presence would be too economically and politically burdensome with even possible reputational risks. Instead, it favors the commercial model (the development of ports purely for commercial use) and the dual-use model (the development of commercial ports with the potential to serve military functions). This option pragmatically suggests using strategic commercial ports to host naval ships, when necessary [Xue 2019].

11 Overseas operations. Ministry of National Defense of the People's Republic of China. URL: http://eng.mod.gov.cn/ news/node_48721.htm (accessed: 28.10.2019). 


\section{China's Dynamics in the UN Peacekeeping: from Passive to Positive Stance}

Indirect options for the safeguard of overseas interests include extended international cooperation, mediation and mostly peacekeeping. For a long time, China was quite skeptical about the UN peacekeeping activities, taking quite passive stance in the SC, if the discussion was not related to the Taiwan issue. In the 1970s, China firmly stayed away from UN peacekeeping due to its normative stance on sovereignty and non-intervention. From the 1980s to the 1990s, China's gradual adjustment of its position towards UN peacekeeping was mainly due to the need of forming a favorable international environment that could benefit its own economic reform and opening up strategy. In 1988, China entered the UN Special Committee on Peacekeeping Operations. For the first time Beijing took an active part in the process in 1990, sending civilian specialists to the Middle East, and first militaries to Cambodia in 1992. But it still refrained from debating the main challenges of that time - Rwanda and Iraq. Its active participation in peacekeeping started since 1999, when the Chinese representative in the SC agreed to carry out an operation in East Timor under Chapter VII of the UN Charter (not requiring the consent of the host country). Since then, China has been participating in peacekeeping more actively, demonstrating full adherence to the UN Charter ${ }^{12}$.

Today Chinese risk-ready businessmen, penetrating new markets and investing in local infrastructure, and Chinese peacekeepers, contributing to the regional security, are equally important for the PRC. China's increasingly active participation in UN peacekeeping serves three major interests: being a responsive power, strengthening the $\mathrm{UN}$, and sharing common concerns for peace and security [He 2007]. In their official speeches the Chinese representatives emphasize the importance of classical principals of peacekeeping, state sovereignty and international cooperation [Jianxin, Shou, Hui 2015].

At present, China occupies the 11th place out of 122 countries contributing and participating in UN peacekeeping operations by the number of personnel. It has deployed 2,458 military and police peacekeepers in nine of the 13 on-going UN peacekeeping

12 Charter of the United Nations. 26 June 1945. URL: https://www.un.org/en/charter-united-nations/ (accessed: 28.10.2019). operations (still less than the number of peacekeepers from Ethiopia, but more in comparison from all SC permanent member-states).

China's strong support for UN peacekeeping is reflected in its active engagement in hotspot issues. Thus, Beijing made significant contributions to the peace process in the Middle East, South Sudan, Darfur in Sudan, the eastern part of DRC, Mali, Afghanistan, refraining from commenting on the possible participation of peacekeepers in the most controversial current conflicts - Syrian and Ukrainian. This demonstrates that Chinese pragmatism does not exclude cautiousness. In addition to peacekeeping operations, Chinese troops are involved in humanitarian assistance, successfully provided to Djibouti, Kenya, Tanzania, Seychelles, Bangladesh, Brunei, Pakistan, Maldives, India and others.

China does not skimp on the financing of peacekeepers, paying the UN much more mandatory contributions. For several years now, the PRC has made the second largest contribution to the UN peacekeeping budget, most of which goes to African countries. In 2018, China invested more than US 192 million in the total budget ${ }^{13}$.

At the UN peacekeeping summit in 2015, Xi Jinping spoke of protecting the world by joint efforts. He stressed that the missions give hope to people in need and are especially important now. After that, $\mathrm{Xi}$ Jinping announced the plans. He promised that China will provide engineers, physicians and technicians for UN operations in a special order, will train 2,000 peacekeepers from other countries, will allocate additional funds to the mission budget and create a unique structure - a permanent rapid response corps of 8,000 people ${ }^{14}$. The President of the PRC also offered Africa a US 100 million military assistance. All promises were clearly kept. In 2015, at the initiative of China, the Peace and Development Trust Fund was created (Beijing allocated US 200 million). Three years later, the first Sino-African Forum

13 United Nations peacekeeping. URL: https://peacekeeping. un.org/en/china (accessed: 28.10.2019).

14 Working Together to Forge a New Partnership of Winwin Cooperation and Create a Community of Shared Future for Mankind. Statement by Xi Jinping at the General Debate of the 70th Session of the UN General Assembly. New York, 28 September 2015. URL: https:/gadebate.un.org/ sites/default/files/gastatements/70/70_ZH_en.pdf (accessed: 28.10.2019). 
on Defense and Security took place ${ }^{15}$, in addition to the Forum on China-Africa Cooperation. China created the remote deployment forces for the United Nations, that have the potential for rapid response ${ }^{16}$.

China's participation in the UN peacekeeping operations is creating a positive image of China in the eyes of the international community and public opinion. Undoubtedly, peacekeeping activities provide Chinese troops with opportunities to improve their qualifications, skills, borrow the experience of foreign partners, train in "operations outside the conditions of the war", and gain experience in participating in military and humanitarian operations. In addition to the ideological ideas about the "harmonious peace" in the development of its peacekeeping potential, China is surely guided by some pragmatic considerations. The concentration of peacekeepers in Africa makes it easier to maintain stability in the region, which is crucial for China in terms of the access to natural resources, like it was in the case of South Sudan [Lynch 2014]. However, the deployment of substantial numbers of peacekeeping troops to the conflict zones like Darfur, Lebanon, and Haiti, which lack significant stocks of natural resources, demonstrates going beyond the realistoriented approach.

\section{African Test for Chinese Security Strategy}

The biggest concentration of the strategic raw resources, including energy, so necessary for the Chinese economy growth, are located in the peripherical countries, mainly in Africa. China's impact and involvement in Africa has been more visible than in other regions. For China Africa remains the main supplier of strategic resources, including oil and metals. China has gained an impressive economic influence there. In 2016, the total volume of foreign trade between China and Africa amounted to US 149,12 billion. China heavily invests in the African region. In 2016, China's non-financial direct investment flow

15 Feature: Overview of 1st China-Africa Peace and Security Forum. China Military Online, 17 July 2019. URL: http://eng.mod.gov.cn/news/2019-07/17/content_4846012.htm (accessed: 28.10.2019).

16 The corps consists of six infantry battalions, engineering and medical teams, as well as transport ships and aircraft, and will be in constant readiness to be sent to the conflict area at the invitation of the UN SC. to Africa reached US 3,3 billion, with a year-on-year growth of $14 \%$ [Zhang, Zhang 2018: 1]. Volumes of the China's investments in African countries are visibly growing: while between 2007 and 2010, China invested US 52.8 billion, between 2015 and 2018, US 121 billion.

But its economic strategy is far more elaborated and mature, than just buying up natural resources. The Chinese investment model involves the massive construction of infrastructure, which meets the real needs of the Africans. The development strategy is fixed in the "Belt and Road Initiative" and the Project of "Three Networks" (high-speed rail network, expressway network and airline network) and "One Industrialization", which, accordingly to the Chinese official declarations, imply win-win outcomes for all involved parties.

Since the beginning of the 21 st century, the security situation in Africa has become complex [Zhang, Zhang 2018]. Africa as an important investment region still suffers from poor internal conditions, high level of political instability, and never-ending armed conflicts [Bokeriya, Omo-Ogbebor 2016]. Obviously, local security situation is posing increasing impact on China's interests and does not favor further expenditure of China's economic interests there. The large volume of investment in the unstable African states has been forcing China recently to take an active part in peacekeeping operations and to increase the presence of its security forces. Although initially intrastate armed conflicts did not affect China's interests directly, over the past decade Chinese workers have been targeted while Chinese-operated oil facilities in Sudan and South Sudan have been attacked by rebels, putting China's adherence to its principle of non-intervention in the internal affairs of other states to the test [Hodzi 2019].

With China's investments and loans increasing in Africa, it's military presence in the region is also growing. China began to increase its military presence here in 1998 with the decision to provide additional financial support to the UN and with direct participation in its peacekeeping operations on the continent. Before launching the military base in 2017, China has started security cooperation with the African Union, supporting conflict resolution and management, particularly where intrastate state armed conflicts directly threaten its interests [Alden et al. 2018]. 
Most Chinese peacekeepers are located in Africa, busy with training local police and military, providing humanitarian assistance, complementing the already existing programs of military and humanitarian cooperation between the PRC and African states. The high level of China's engagement is offering an alternative to France's military presence. The PLA also benefits from peacekeeping, as Chinese servicemen provide to their homeland new connections with local power structures. Moreover the Chinese military personnel and specialists assigned to the missions are gaining the experience closest to the combat conditions that can be gained in another country without starting a full-scale military operation. The Chinese army is limited in the possibilities of remote deployment of forces - peacekeeping gives unique access to new areas. China's Navy's participation in maritime security in Africa has also increased. In late December 2008 China launched its first anti-piracy mission for protecting Chinese ships and crews, responding to the piracy increase in the Gulf of Aden.

Most probably, Africa will be a test for Beijing's "great power ambitions", which are increasingly being voiced by the Chinese leadership. The creation of the military base in Djibouti and the intensification of China's peacekeeping activities in Africa fueled general anxiety regarding the scope of the Chinese penetration into the region. However, Beijing has not yet shown clear ambitions to build up more military presence on the continent.

\section{From Active Non-Intervention Policy to Military "Muscle" and Constructive Engagement?}

The current IR discourse on the intervention behavior of rising powers in the intrastate armed conflicts in developing countries is still quite limited [Grachikov 2019], but it will obviously get some dynamics in the near future as there is a gradual but careful departure from non-intervention policy in the practical sphere. In addition, there is an ongoing domestic debate in China on non-interference, demonstrating some shift in the understanding and approaching the principle.

"Non-interference in the internal affairs of other states" has been the fundamental principle of China's foreign policy, often used for describing peaceful and mutually beneficial way of economic penetration into the markets of other countries. Overseas interests and new security threats putting Chinese lives at risk contributed to persuading China to rethink non-interference issue. Although today's China holy believes in principles of consent, impartiality, and non-use of force, it's practical approach has undergone some changes. Beijing has in principle endorsed "responsibility to protect" (R2P) by supporting the 2005 World Summit Outcome, but it has never embraced the interventionism embodied in the concept [Coning, Peter 2019: 253-276], giving full support to the Pillar One - "each individual state has a responsibility to protect its population from mass atrocities" [Lei 2011].

In 2012 the Institute of International Studies, a top Chinese think tank affiliated to the Chinese Ministry of Foreign Affairs, coined the concept of "protection of civilians" (PoC) or "responsible protection" (RP), that Beijing basically agrees to, but not yet officially endorsed [Coning, Peter 2019: 265]. The mission of "responsible protection" as an intervention operation is to protect innocent civilians in the country concerned as well as regional peace and stability, rather than specific political factions or armed forces.

China's intervention in the intrastate conflicts varies with each case. But all cases demonstrate that new security conditions made China more willing to deploy combat forces alongside traditional support units. When civil war broke out in 2013 in South Sudan, where many Chinese energy companies were present, Beijing sent its special envoy for African affairs, Ambassador Zhong Jianhua, to mediate between the conflicting parties. Trying to secure its energy resources and protect investments, China was forced to play a significant role in negotiating with the opposition force and, subsequently, the enemy of its long-time ally. Actually, it was one of its first experiences in officially intervening in another country's internal political processes. But Beijing refused the same type of mediation for the conflict in the Central African Republic.

Chinese citizens and companies working overseas were involved in multiple security incidents. In Libya in 2011 the evacuation of 36,000 workers involving a military deployment beyond China's borders was widely covered by official media as a success and was very well-received in China. Regarding this conflict, China argued that "there must 
be no attempt at regime change or involvement in civil war by any party under the guise of protecting civilians," but at the same time it was largely supportive of the French military intervention in Mali. In 2015, while carrying out anti-piracy patrols off the coast of Somalia, Chinese naval frigates were diverted to Yemen to evacuate people, which were later on taken across the Red Sea to Djibouti, to take flights home. China's navy evacuated from Yemen's southern port of Aden 225 foreign nationals (from Pakistan, Ethiopia, Singapore, the UK, Italy and Germany) and almost 600 Chinese citizens. Beijing declared, that it was the first military mission with warships to rescue foreign nationals, and only the second mission to evacuate its own citizens, trapped by the fighting in a conflict zone. In sum, China conducted a dozen other evacuations in Thailand, Syria, Vietnam, etc.

China's strategy is mostly founded on the pragmatism and influenced by the whole set of factors, including the exterior. For instance, in Venezuela, which is undoubtedly an important economic partner and a platform for China to strengthen its interests in Latin America, Beijing is not undertaking any enforcement measures. However in general, China's engagement in risky countries, initially characterized as non-interventionist in its pursuit of economic interests, is becoming more deeply involved in the region's security landscape. On the one hand, China takes very cautious position regarding the "R2P" doctrine, declaring that external forces, that have made several direct military interventions in African security affairs, not only dominated the local security trend, but also brought more disasters and turbulence and brought more challenges to China's interests there. But, on the other hand, many experts point out, that in order to connect with the international community better, China's principle of non-interference in internal affairs needs to be given new meanings when necessary and therefore optimized [Zhang, Zhang 2018].

Since non-interference remains crucial for Chinese core interests, China would mostly follow and proclaim this longstanding principle further in its conceptual official framework. In addition, such strategy could be beneficial, taken into account the events of the Arab Spring. Even in its largest evacuation mission in Libya, China acted in accordance with non-interference with minimum military involvement and formal approval from relevant states. However, normative developments in the international system, forging the need to protect China's overseas interests, have explore alternative policy options and revealed the need for the Chinese military to be more actively engaged. So, in its practical response China has been more flexible regarding the non-interference, leaning on the necessity of the so called constructive engagement. As rightly noted Pang Zhongying, "Dependence on overseas resources, markets and energy will oblige China to adjust its foreign policy by, de facto, abandoning some of its 'nos,' such as 'non-interference' and 'not taking the lead" [Ratner et al. 2015: 15].

Constructive engagement is described in the Chinese academic literature in quite positive way without any mentioning of the regime change option, external military repression, invasion or occupation. According to Wang Yizhou, constructive engagement is to assist the countries concerned to enhance their abilities to choose their own development directions with China's adjustment and resources under the condition of full respect for the people and majority political factions of the country concerned (see: [Zhang, Zhang 2018]). Zhao Huasheng describes the final goal of constructive engagement as preventing the security situation from deteriorating, and to promote national and regional peace and stability (see: [Zhang, Zhang 2018]). Zhou Shixin presents constructive engagement as a flexible policy under the concept of intervention in a broad sense, but going beyond the traditional intervention (see: [Zhang, Zhang 2018]).

Declaring the goal of assisting unstable countries to address their problems by themselves and stressing principle of full respect of the political will of the concerned countries, a more active engagement creates quite sensible problems for the Chinese policy: reputational risks in case there are too close and not enough transparent links with certain governments, risks to its business interests posed by mercurial leaders and weak regimes, and risks faced by its citizens working in the unstable states and dangerous conditions.

For the past years China was preoccupied by finding a balance between the non-intervention principle and the protection of its interests in foreign countries, dominated by long-lasting intrastate armed conflicts. As a result, China has smoothly adopted the transition strategy from non-intervention into 
internal affairs to a more proactive non-indifference approach, acting as a mediator between conflict parties. In its few mediation efforts Beijing mostly prefers not to use official diplomacy and international institutions (track-one diplomacy), but rather "special envoy" diplomacy with political envoys as key mediators, empowered to deal with crises (for instance, as in the cases of Sudan in 2007, Libya and Syria since 2011, Myanmar in 2013, Afghanistan in 2014, etc.). Plus China stands for informal channels of influence as party-to-party relations. The degree of the China's involvement will depend on the level of its responsibility at the global level, particularly since China is undergoing through a higher degree of international pressure in order to take more obligations.

\section{Concluding Remarks}

In the "new era", a rising China has become more engaged, ambitious and experienced in international affairs. China's new identity of the biggest emerging power is certainly shaping its new security and peacekeeping doctrine, which also serves the global power projection. China favors the whole set of diplomatic means over military as the primary tools to secure its interests. But China shows its readiness to follow its "responsible" path and more "robust" peacekeeping, especially under international pressure to assume global responsibilities commensurate with the rapidly expanding economic interests.

At the same time China continues investment in peacekeeping operations and counterpiracy missions. It strongly supports the UN, both in financing peacekeeping operations, and providing peacekeeping personnel. The UN support strategy helps China to expand its diplomacy throughout the developing world. The reputation of China as a credible security partner would be of vital importance in the situations when the "South" states would have to decide to host a Chinese base on their soil, if necessary. Obviously, the current proactive peacekeeping strategy of China is having a general impact on the UN peacekeeping model, which is increasingly becoming Chinese. Providing money, people, and authority forms a solid basis for China to become a new potential peacekeeping leader and prove that the USA is not the only and perhaps not the best guarantor of world stability.

China feels itself more vulnerable in connection with its Belt and Road initiative, and the new security conditions might make the whole situation worse and ultimately lead to China assuming a new and quite different security role. Actually, China follows the path of other leading powers that developed military activities abroad, pursuing economic interests. Obviously, in the near future China will be carrying out a number of overseas missions, including humanitarian assistance and disaster relief, evacuation operations, defense of sea lanes, stabilization operations, peacekeeping and counterterrorism missions. Apparently, China would provide greater input into conflict resolution with more focus on political stabilization in the countries, given its economic interests and expanded international commitments. This suggests further growing force projection capabilities. China is also likely to advance training, advisory and support missions for its many partners as part of its own version of the American strategy "leadership from the rear".

In recent years the China's efforts have been directed to peacekeeping engagement and evacuation of its nationals from conflict zones. The massive evacuation from Libya created for the PLA Navy and Air Force a true precedent, repeated in 2015, when the PLA Navy task force in the Gulf of Aden was redirected to evacuate from Yemen through Djibouti, including foreigners. China was also engaged in protecting commercial shipping in the Gulf of Aden. Currently, the PLA focuses on far-seas maritime missions, it has not yet had any land-based operation with deployment of ground forces overseas. And most probably this trend is likely to continue in the future.

The expansion of Chinese overseas interests and the need to protect a growing number of Chinese nationals have revealed the limits of China's traditional approach and generated new thinking about non-interference. Responding to overseas security crises through military actions would be mostly shaped by events (case-by-case approach) and inspired by political rather than legal motivations. Today's Chinese approach to overseas military operations is characterized by a relative lack of institutionalization. There is little evidence to predict that China intends to construct more military bases, being fully involved in the security landscape. However, many new elements for a new constructive engagement emerge - conceptual narrative, political support, geopolitical competition, growing capacities 
and new security conditions. Therefore, the central focus for both academic community and decisionmakers might be on improving the crisis-management model, defining the conditions of practical military protection for Chinese nationals and assets, and future course of action regarding overseas military bases.

Received / Поступила в редакцию: 27.06.2019 Accepted / Принята к публикации: 15.09.2019

\section{References / Библиографический список}

Alden, Ch., Alao, A., Chun, Zh. \& Barber, L. (Eds.). (2018). China and Africa. Building Peace and Security Cooperation on the Continent. London: Palgrave Macmillan. DOI: 10.1007/978-3-319-52893-9

Bokeriya, S.A. \& Omo-Ogbebor, D.O. (2016). Boko Haram: a New Paradigm to West Africa Security Challenges. Vestnik RUDN. International Relations, 16 (2), 274-284.

Campbell, I., Wheeler., Th., Attree, L., Butler, D.M. \& Mariani, B. (2012). China and Conflict-Affected States. Between Principle and Pragmatism. London: Safeworld.

Cheng Guo, Chen Lu, Degterev, D.A. \& Zhao Jelin. (2019). Geopolitical Implications of China's “One Belt One Road" Strategy. Vestnik RUDN. International Relations, 19 (1), 77-88. DOI: 10.22363/2313-0660-2019-19-1-77-88

Coning, C. \& Peter, M. (Eds.) (2019). United Nations Peace Operations in a Changing Global Order. London: Palgrave Macmillan. DOI 10.1007/978-3-319-99106-1

Duchâtel, M., Bräuner, O. \& Hang, Z. (2014). Protecting China's Overseas Interests: The Slow Shift Away from Non-interference. SIPRI Policy Paper 41. Stockholm: Stockholm International Peace Research Institute. URL: https://www.sipri.org/sites/default/files/files/PP/SIPRIPP41.pdf (accessed: 28.10.2019).

Galtung, J. (1969). Violence, Peace, and Peace Research. Journal of Peace Research, 6 (03), 167-191. DOI: $10.1177 / 002234336900600301$

Grachikov, E.V. (2019). Chinese School of International Relations. How Theory Creates Diplomatic Strategy and Vice Versa. Russia in Global Affairs, 17 (2), 154-173. DOI: 10.31278/1810-6374-2019-17-2-154-173

He, Y. (2007). China's Changing Policy on UN Peacekeeping Operations. Asia Paper, Institute for Security and Development Policy, Stockholm.

Hodzi, O. (2019). The End of China's Non-Intervention Policy in Africa. London: Palgrave Macmillan. DOI: 10.1007/978-3-319-97349-4

Ikenberry, J. (2008). The Rise of China and the Future of the West: Can the Liberal System Survive. Foreign Affairs, 87 (1), $23-37$.

Lei, Zh. (2011). Two Pillars of China's Global Peace Engagement Strategy: UN Peacekeeping and International Peacebuilding. International Peacekeeping, 18 (03), 344-362. DOI: 10.1080/13533312.2011.563107

Lin-Greenberg, E. (2010). Dragon Boats: Assessing China's Anti-Piracy Operations in the Gulf of Aden. Defense and Security Analysis, 26 (02), 213-230.

Lynch, C. (2014). UN Peacekeepers to Protect China's Oil Interests in South Sudan. Foreign Policy, June 16. URL: https:/foreignpolicy.com/2014/06/16/u-n-peacekeepers-to-protect-chinas-oil-interests-in-south-sudan/ (accessed: 28.10.2019).

Ratner, E., Colby, E., Erickson, A., Hosford, Z. \& Sullivan, A. (2015). More Willing and Able: Charting China's International Security Activism. Center for a New American Security. URL: https://www.cnas.org/publications/reports/morewilling-and-able-charting-chinas-international-security-activism (accessed: 28.10.2019).

Rolland, N. (Eds.) (2019). Securing the Belt and Road Initiative China's Evolving Military Engagement Along the Silk Roads. The National Bureau of Asian Research. September 2019. NBR special report No. 80. URL: https://www.nbr.org/wpcontent/uploads/pdfs/publications/sr80 securing the belt and road sep2019.pdf (accessed: 28.10.2019).

Seesaghur, H.N. \& Robertson, E. (2016). An Overview of the Chinese Agenda: Global Sustainable Peace and Development. Acta Universitatis Danubius. Relationes Internationales, 9 (02), 154-171.

Suzuki, Sh. (2011). Why Does China Participate in Intrusive Peacekeeping? Understanding Paternalistic Chinese Discourses on Development and Intervention. International Peacekeeping, 18 (03), 271-285. DOI: 10.1080/13533312.2011.563079

Wuthnow, J. (2017). Chinese Perspectives on the Belt and Road Initiative: Strategic Rationales, Risks, and Implications. Center for the Study of Chinese Military Affairs, Institute for National Strategic Studies, National Defense University. China Strategic Perspectives, No. 12. URL: https://inss.ndu.edu/Portals/68/Documents/stratperspective/china/ ChinaPerspectives-12.pdf (accessed: 28.10.2019).

Xue G. (2019). The Potential Dual Use of Support Facilities in the Belt and Road Initiative. In: Rolland, N. (Eds.). Securing the Belt and Road Initiative China's Evolving Military Engagement Along the Silk Roads. The National Bureau of Asian Research. September 2019. NBR special report No. 80 P. 47-59. URL: https://www.nbr.org/wp-content/uploads/pdfs/ publications/sr80_securing_the_belt_and_road_sep2019.pdf (accessed: 28.10.2019).

Zhang, Ch. \& Zhang, M. (2018). China-Africa Cooperation in the Peace and Security Issues. National Think Tank. ChinaAfrica Friendly Cooperation in the New Era Think Tank Reports. No. 4. China Social Sciences Press. 
Jianxin, L., Shou, W. \& Hui, Zh. (2015). Guoji weihe xue [A Study on International Peacekeeping]. Beijing: Guofang daxue chuban she [Beijing: National Defense University Press]. (In Chinese).

Yaqing, Q. (Eds.). (2019). Quanqiu zhili: Duoyuan shijie de zhixu chongjian [Global Governance: Rebuilding of Order in Multiplex World]. Beijing: Shijie zhishi chuban she [Beijing: World Knowledge Press]. (In Chinese).

\begin{abstract}
About the author: Khudaykulova Alexandra Victorovna - PhD (Political Sciences), Associate Professor of Department of Applied International Analysis, Moscow State Institute of International Relations of MFA of Russia (MGIMO University); Associate Professor of Department of Theory and History of International Relations, Peoples' Friendship University of Russia (RUDN University) (e-mail: alexandra_77@mail.ru).
\end{abstract}

Сведения об авторе: Худайкулова Александра Викторовна - кандидат политических наук, доцент кафедры прикладного анализа международных проблем МГИМО МИД России; доцент кафедры теории и истории международных отношений Российского университета дружбы народов (e-mail: alexandra_77@mail.ru). 